\title{
Pengaruh Kualitas Layanan Terhadap Kepuasan Pelanggan Starbucks Coffee Plaza Kampung Kemang
}

\author{
Ugeng Budi Haryoko ${ }^{1}$, Fauziah Septiani ${ }^{2}$, Risnalinda ${ }^{3}$ \\ Universitas Pamulang \\ Email : ugengbudiunpam@gmail.com
}

\begin{abstract}
Abstrak. Penelitian ini bertujuan untuk mengetahui "pengaruh kualitas layanan terhadap kepuasan pelanggan di Starbucks Coffee Plaza Kampung Kemang".

Jenis penelitian deskriptif kuantitatif, metode dalam penelitian ini dengan mendistribusikan kuesioner secara langsung kepada pelanggan Starbucks Coffee Plaza Kampung Kemang. Analisis metode pengolahan data adalah: uji validasi, uji reliabilitas, uji korelasi product moment, uji koefisien determinasi, uji signifikan / uji hipotesis (uji t), uji regresi linier sederhana

Berdasarkan hasil analisis perhitungan koefisien korelasi product moment (rxy) 0,886 menunjukkan besarnya pengaruh kualitas layanan terhadap kepuasan pelanggan di Starbucks Coffee Plaza Kampung Kemang memiliki tingkat hubungan yang sangat kuat, Dengan koefisien determinasi $(R)$ sama dengan $88,6 \%$, ini menunjukkan besarnya kontribusi bahwa kualitas layanan terhadap kepuasan pelanggan di Starbucks Coffee Plaza Kampung Kemang adalah 88,6\%, sedangkan 11,4\% Sisa tidak ada yang lain yang bisa dipelajari. Hasil kajian ini dapat menyimpulkan bahwa ada pengaruh seperti kualitas layanan terhadap kepuasan pelanggan di Starbucks Coffee Plaza Kampung Kemang.
\end{abstract}

Keywords: Kualitas Pelayanan, Kepuasan Pelanggan.

\begin{abstract}
This lesson aims to determine effect of service quality on customer satisfaction at Starbucks Coffee Plaza Kampung Kemang ".

This type of quantitative descriptive research, the method in this study by distributing questionnaires directly to Starbucks Coffee Plaza Kampung Kemang customers. Analysis methods used in data processing are: validation test, reliability test, product moment correlation test, coefficient to determination test, significant test / hypothesis test (t test), simple linear regression test

Based on the analysis results of the calculation of product moment correlation coefficient (rxy) 0.886 shows the magnitude of the effect of service quality on customer satisfaction at Starbucks Coffee Plaza Kampung Kemang has a very strong relationship level, With a coefficient of determination $(R)$ of $88.6 \%$, this shows the magnitude of the contribution that the quality of service to customer satisfaction at Starbucks Coffee Plaza Kampung Kemang is $88.6 \%$, while the remaining $11.4 \%$ is influenced by other factors not yet examined. The results of this study can conclude that there is an influence between service quality on customer satisfaction at Starbucks Coffee Plaza Kampung Kemang.
\end{abstract}

Key words Service Quality, Customer Satisfaction. 


\section{A. PENDAHULUAN}

Untuk Menjadi perusahaan yang unggul tidaklah mudah, keterampilan manajemen yang baik diperlukan untuk dapat memberikan layanan berkualitas yang bahkan melebihi harapan konsumen. Kualitas layanan memainkan peran penting dalam suatu perusahaan karena akan mempengaruhi kepuasan pelanggan, sehingga menghasilkan loyalitas. Konsumen yang memiliki loyalitas tinggi kepada perusahaan akan memiliki dampak positif langsung pada kemajuan perusahaan dalam jangka pendek dan panjang.

Ketika mengukur tingkat kualitas layanan dan kepuasan pelanggan, Starbucks Coffee melakukan survei konsumen melalui Suara Pelanggan (CV). Dengan CV, Starbucks Coffee dapat menemukan akuisisi bulanan CV terkait dengan layanan, produk, dan kepuasan pelanggan. Menurut manajemen Starbucks, Coffee Plaza Kampung Kemang, kepuasan pelanggan dapat dilihat pada jumlah konsumen yang volume penjualannya belum memenuhi tujuan penjualan, dan meskipun demikian dapat ditemukan pada tabel berikut:

Tabel 1

Data pengunjung \& Omset Starbucks Coffee Plaza Kampung Kemang Tahun 2014 - 2016

\begin{tabular}{|r|c|c|c|c|}
\hline No & Tahun & $\begin{array}{c}\text { Total Jumlah } \\
\text { Pengunjung (Orang) }\end{array}$ & $\begin{array}{c}\text { Omset Per } \\
\text { Tahun }\end{array}$ & Target Per Tahun \\
\hline 1 & 2014 & 49.248 & Rp 1.947 .870 .000 & $\operatorname{Rp~2.300.000.000~}$ \\
\hline 2 & 2015 & 53.136 & Rp 2.166.480.000 & Rp 2.400.000.000 \\
\hline 3 & 2016 & 57.024 & Rp 2.284.875.000 & Rp 2.500.000.000 \\
\hline
\end{tabular}

Sumber: Starbucks Coffee Plaza Kampung Kemang2014 -2016

Dari data sebelumnya dapat disimpulkan bahwa jumlah pengunjung telah meningkat, tetapi tidak mencapai tujuan yang disyaratkan oleh administrasi Starbucks. kompetisi, yang pada akhirnya berfungsi sebagai strategi untuk mencapai tujuan perusahaan dalam jangka pendek dan panjang, berdasarkan latar belakang ini, penulis mengangkat tema "Pengaruh kualitas layanan terhadap kepuasan dari pelanggan Starbucks Coffee Plaza Kampung Kemang "

Rumusan masalah dalam penelitian ini : Bagaimana kualitas layanan Starbucks Coffee Plaza Kampung Kemang?,Bagaimana kepuasan pelanggan Starbucks Coffee Plaza Kampung Kemang?, Seberapa besar pentingnya pengaruh kualitas layanan terhadap kepuasan pelanggan Starbucks Coffee Plaza Kampung Kemang?

Tujuan dari penelitian ini adalah: Untuk menemukan kualitas layanan diberikan kepada konsumen di Starbucks Coffee Plaza Kampung Kemang, Untuk mengetahui kepuasan pelanggan dengan konsumen di Starbucks Coffee Plaza Kampung Kemang, Untuk mengetahui sejauh mana pengaruh kualitas layanan diberikan terhadap kepuasan 
Volume $3 \cdot$ Nomor $2 \cdot$ Februari 2020

Pege (Hal.) : $40-47$

(C) Universitas Pamulang

JL.Surya Kencana No.1 Pamulang, Tangerang Selatan - Banten

Telp. (021) 7412566, Fax (021) 7412491

website. : Email : jurnalmarketing.unpam@gmail.com

http://www.openjournal.unpam.ac.id/index.php/JPK

pelanggan di Starbucks Coffee Plaza Kampung Kemang.

\section{B. KAJIAN LITERATUR}

Menurut Parasuraman, Zeithaml dan Berry (1985) yang dikutip oleh Fandy Tjiptono (2012: 174), ada lima dimensi utama untuk mengukur kualitas layanan. Dimensi utama meliputi:

1. Realibilitas (Realibility), sehubungan dengan kemampuan Perusahaan untuk menyediakan layanan yang diberikan secara adil dan memuaskan.

2. Daya Tanggap (Responsiveness), mengenai ketersediaan dan kemampuan penyedia layanan membantu pelanggan dan merespons mereka dengan segera.

3. Jaminan (Assurance), sehubungan dengan pengetahuan dan kesopanan karyawan dan kemampuan mereka untuk membangun kepercayaan dan kepercayaan pelanggan.

4. Empati (Empathy), berarti bahwa perusahaan memahami masalah pelanggannya dan bekerja untuk kepentingan terbaik pelanggan, selain dipertimbangkan dan pemahaman yang dipersonalisasi untuk kebutuhan individu pelanggan ini.

5. Bukti Fisik (Tangibles), mengenai penampilan fisik dari fasilitas layanan perusahaan, peralatan / persediaan, sumber daya manusia dan materi komunikasi.

Menurut Kotler dan Keller (2009: 138), Kepuasan adalah perasaan senang atau frustrasi seseorang sebagai hasil membandingkan perasaan (atau hasil) produk dengan harapan. Seperti yang diharapkan, pelanggan tidak puas. Jika acara itu memenuhi harapan, pelanggan akan puas. Jika acara melampaui harapan, pelanggan

Posting komentar atau balas komentar. Dari definisi ini, dapat dikatakan bahwa kepuasan adalah rasa kepuasan atau frustrasi seseorang tentang produk yang ditawarkan bersama dengan harapan yang diharapkan.

\section{METODOLOGI PENELITIAN}

P Penelitian ini dilakukan di Starbuck Cofee Plaza Kampung Kemang Highway Retail shop no. 98 di Jakarta Selatan. Dalam penelitian ini, populasi adalah 57024 dan sampel sebanyak 100. Metode analisis data yang digunakan adalah uji reliabilitas, uji kepercayaan, regresi linier sederhana, koefisien koreksi, standar deviasi, dan uji signifikan (uji t)

\section{HASIL DAN PEMBAHASAN}

\section{Hasil Analisis Statistik Deskriftif}

Tabel 2

Tanggapan Responden Terhadap Kualitas Pelayanan (X)

\begin{tabular}{|l|l|r|r|r|r|r|}
\hline No & \multicolumn{1}{|c|}{ Pernyataan } & \multicolumn{1}{l|}{ STS } & TS & R & S & SS \\
\hline & Keandalan (Realibity) & & & & & \\
\hline 1 & $\begin{array}{l}\text { Petugas cekatan dalam } \\
\text { melakukan Pelayanan }\end{array}$ & 2 & 5 & 25 & 67 & 1 \\
\hline 2 & Petugas menyediakan & 0 & 8 & 23 & 66 & 3 \\
\hline
\end{tabular}


Volume 3 • Nomor 2 • Februari 2020

Pege (Hal.) : $40-47$

(C) Universitas Pamulang

JL.Surya Kencana No.1 Pamulang, Tangerang Selatan - Banten

website. :

Telp. (021) 7412566, Fax (021) 7412491

http://www.openjournal.unpam.ac.id/index.php/JPK

Email : jurnalmarketing.unpam@gmail.com

\begin{tabular}{|c|c|c|c|c|c|c|}
\hline & $\begin{array}{l}\text { layanan sesuai dengan } \\
\text { waktu yang dijanjikan }\end{array}$ & & & & & \\
\hline & $\begin{array}{l}\text { Daya Tanggap } \\
\text { (Responsiveness) }\end{array}$ & & & & & \\
\hline 3 & $\begin{array}{l}\text { Pegawai Starbucks mampu } \\
\text { menanamkan kepercayaan } \\
\text { pada pelanggan }\end{array}$ & 0 & 5 & 20 & 70 & 5 \\
\hline \multirow[t]{2}{*}{4} & $\begin{array}{l}\text { Dapat melayani segala } \\
\text { keluhan pelanggan }\end{array}$ & 0 & 2 & 20 & 70 & 8 \\
\hline & Jaminan (Assurance) & & & & & \\
\hline 5 & $\begin{array}{l}\text { Pelanggan merasa aman } \\
\text { dalam Bertransaksi }\end{array}$ & 0 & 6 & 20 & 68 & 6 \\
\hline \multirow[t]{2}{*}{6} & $\begin{array}{ll}\text { Karyawan } & \text { Starbucks } \\
\text { memahami } & \text { mengenai } \\
\text { produk yang ditawarkan }\end{array}$ & 0 & 7 & 24 & 65 & 4 \\
\hline & Empati (Empaty) & & & & & \\
\hline 7 & $\begin{array}{l}\text { Mengerti keinginan dan } \\
\text { kebutuhan pelanggan }\end{array}$ & 0 & 4 & 23 & 67 & 6 \\
\hline \multirow[t]{2}{*}{8} & $\begin{array}{l}\text { Petugas selalu } \\
\text { mengutamakan } \\
\text { kepentingan pelanggan }\end{array}$ & 0 & 5 & 21 & 73 & 1 \\
\hline & Bukti Fisik (Tangibles) & & & & & \\
\hline 9 & $\begin{array}{ll}\text { Penampilan } & \text { karyawan } \\
\text { bersih dan rapi }\end{array}$ & 0 & 4 & 22 & 69 & 5 \\
\hline \multirow[t]{4}{*}{10} & $\begin{array}{l}\text { Peralatan, perlengkapan, da } \\
\text { n sarana modern }\end{array}$ & 0 & 4 & 25 & 66 & 5 \\
\hline & Jumlah & 2 & 50 & 223 & 681 & 44 \\
\hline & Rata-rata & 0,2 & 5 & 22,3 & 68,1 & 4,4 \\
\hline & Persentase (\%) & $0,2 \%$ & $5,0 \%$ & $22,3 \%$ & $68,1 \%$ & $4,4 \%$ \\
\hline
\end{tabular}

Berdasarkan tabel sebelumnya, kualitas respons rata-rata untuk variabel kualitas layanan (variabel $\mathrm{x}$ ) sangat baik.

Tabel 3

Tanggapan Responden Terhadap Kepuasan Pelanggan ( $Y$ )

\begin{tabular}{|l|l|l|l|l|l|l|}
\hline No & \multicolumn{1}{|c|}{ Pernyataan } & STS & T & R & S & S \\
\hline & Kesesuaian Harapan & & & & & \\
\hline 1 & $\begin{array}{l}\text { Saya merasa puas } \\
\text { dengan kesopanan \& } \\
\text { keramahan yang dimiliki } \\
\text { karyawan Starbucks }\end{array}$ & 0 & 2 & 24 & 71 & 3 \\
\hline & $\begin{array}{l}\text { Saya puas dengan } \\
\text { fasilitas (meja, kursi, } \\
\text { perlengkapan minum dll) } \\
\text { yang disediakan oleh }\end{array}$ & 0 & 3 & 24 & 68 & 5 \\
\hline
\end{tabular}


Volume 3 • Nomor 2 • Februari 2020

Pege (Hal.) : $40-47$

(C) Universitas Pamulang

JL.Surya Kencana No.1 Pamulang, Tangerang Selatan - Banten

website. :

Telp. (021) 7412566, Fax (021) 7412491

http://www.openjournal.unpam.ac.id/index.php/JPK

Email : jurnalmarketing.unpam@gmail.com

\begin{tabular}{|c|c|c|c|c|c|c|}
\hline & $\begin{array}{ll}\text { Starbuck bersih } & \text { dan } \\
\text { dalam keadaan baik } & \end{array}$ & & & & & \\
\hline 3 & $\begin{array}{lr}\text { Produk Starbucks } & \text { yang } \\
\text { disajikan } & \text { selalu } \\
\text { berkualitas baik } & \end{array}$ & 0 & 8 & 26 & 60 & 6 \\
\hline \multirow[t]{2}{*}{4} & $\begin{array}{l}\text { Fasilitas pendukung pada } \\
\text { kedai kopi Starbucks ini } \\
\text { (wifi, sound system, } \\
\text { pencahayaan,dll) sangat } \\
\text { baik. }\end{array}$ & 0 & 5 & 28 & 63 & 4 \\
\hline & $\begin{array}{ll}\text { Minat } & \text { Berkunjung } \\
\text { Kembali } & \end{array}$ & & & & & \\
\hline 5 & $\begin{array}{l}\text { Saya berminat untuk } \\
\text { mengunjungi kembali } \\
\text { kedai kopi Starbucks }\end{array}$ & 0 & 2 & 28 & 63 & 7 \\
\hline 6 & $\begin{array}{l}\text { Saya berminat untuk } \\
\text { membeli produk Starbucks } \\
\text { kembali }\end{array}$ & 0 & 5 & 28 & 65 & 2 \\
\hline \multirow[t]{2}{*}{7} & $\begin{array}{lrr}\text { Saya berniat } & \text { untuk } \\
\text { mencoba variasi } & \text { menu } \\
\text { baru } & \text { lainnya } \\
\text { yang } & \text { ditawarkan } \\
\text { Starbucks } & \text { saat berkunjung } \\
\text { kembali. }\end{array}$ & 0 & 3 & 27 & 66 & 4 \\
\hline & $\begin{array}{l}\text { Kesediaan } \\
\text { merekomendasikan }\end{array}$ & & & & & \\
\hline 8 & $\begin{array}{l}\text { Akan merekomendasikan } \\
\text { teman atau kerabat untuk } \\
\text { membeli produk Starbucks }\end{array}$ & 0 & 2 & 25 & 67 & 6 \\
\hline 9 & $\begin{array}{l}\text { Memberikan informasi } \\
\text { kepada orang lain tentang } \\
\text { keunggulan produk } \\
\text { Starbucks }\end{array}$ & 0 & 2 & 26 & 66 & 6 \\
\hline \multirow[t]{4}{*}{10} & $\begin{array}{l}\text { Merekomendasikan } \\
\text { kepada orang lain agar } \\
\text { berkunjung ke Starbucks }\end{array}$ & 0 & 3 & 26 & 68 & 3 \\
\hline & Jumlah & 0 & 35 & 262 & 657 & 46 \\
\hline & Rata-rata & 0 & 3,5 & 26,2 & 65,7 & 4,6 \\
\hline & Persentase (\%) & $0,0 \%$ & $3,5 \%$ & $26,2 \%$ & $65,7 \%$ & $4,6 \%$ \\
\hline
\end{tabular}

Berdasarkan tabel sebelumnya, kualitas respons rata-rata untuk variabel kualitas layanan (variabel $\mathrm{x}$ ) sangat baik. 
Volume $3 \cdot$ Nomor $2 \cdot$ Februari 2020

Pege (Hal.) : $40-47$

(C) Universitas Pamulang

JL.Surya Kencana No.1 Pamulang, Tangerang Selatan - Banten

Telp. (021) 7412566, Fax (021) 7412491

website. : Email : jurnalmarketing.unpam@gmail.com

http://www.openjournal.unpam.ac.id/index.php/JPK

\section{Hasil Analisis Data Statistik Inferensial}

\section{Hasil Uji Regresi Linear Sederhana}

Uji regresi mudah untuk menemukan hubungan antara variabel dalam kualitas layanan $(\mathrm{X})$ dan kepuasan pelanggan $(Y)$ sebagai hubungan sebab akibat antara variabel independen dan dependen. Ini perhitungannya.

$Y=a+b x$

Sebelum melakukan kalkulator regresi linier sederhana di atas, nilai a dan b harus diketahui, perhitungan nilai $b$ a berikut dapat digunakan menggunakan kalimat berikut:

$Y=7,197+0,806 X$

Dari persamaan regresi sebelumnya, dapat diartikan sebagai:

a. 7197 berarti bahwa jika kualitas layanan $(\mathrm{X})$ adalah 0 , kepuasan pelanggan $(\mathrm{Y})$ adalah 7197.

b. Menunjukkan bahwa ada hubungan positif antara kualitas layanan dan Kepuasan Pelanggan. Ini berarti meningkatkan kualitas layanan akan meningkatkan Kepuasan Pelanggan di Starbucks Coffee Plaza Kampung Kemang.

\section{Uji Korelasi Product Moment}

$=0,886$

Dari komputasi model matematika untuk hubungan korelasi Pearson, ada hubungan positif antara kualitas layanan dan kepuasan pelanggan, yang mirip dengan ar. $=0,886$ milik kategori terkuat $(0,80-1000)$

\section{Uji Koefesiensi Determinasi}

Selain itu, untuk menentukan dampak kualitas layanan terhadap kepuasan pelanggan, gunakan aturan berikut:

$$
\begin{aligned}
\mathrm{KD} & =\mathrm{r} 2 \times 100 \% \\
& =0,886 \times 100 \% \\
& =0,886 \times 100 \%=88,6 \%
\end{aligned}
$$

Hal ini menunjukkan bahwa besarnya hubungan antara variabel $x$ (kualitas layanan) dan variabel y (kepuasan pelanggan) adalah $88,6 \%$ dan sisanya $11,4 \%$ dipengaruhi oleh faktor fungsional lain yang tidak dipertimbangkan oleh penulis.

\section{Uji Hipotesis}

\section{Diketahui :}

$$
r=0,886 \quad n=100
$$

$$
\begin{aligned}
t_{\text {hitung }} & =\frac{r \sqrt{n-2}}{\sqrt{1-r^{2}}} \\
t_{\text {hitung }} & =\frac{0,886 \sqrt{100-2}}{\sqrt{1-0,886^{2}}}
\end{aligned}
$$


Volume $3 \cdot$ Nomor $2 \cdot$ Februari 2020

Pege (Hal.) : $40-47$

(C) Universitas Pamulang

JL.Surya Kencana No.1 Pamulang, Tangerang Selatan - Banten

Telp. (021) 7412566, Fax (021) 7412491

website. : Email : jurnalmarketing.unpam@gmail.com

http://www.openjournal.unpam.ac.id/index.php/JPK

$t_{\text {hitung }}=\frac{0,886 \sqrt{100}}{\sqrt{1-0,785}}$

$t_{\text {hitung }}=\frac{8,86}{0,215}$

$t_{\text {hitung }}=41,209$

Buat keputusan menggunakan perbandingan nomor tabel dengan kriteria berikut:

Jika t-tabel ditolak $>$ tabel $\mathrm{H} 0$, Ha (penting) diterima, Jika tabel $<\mathrm{H}$ tabel ditolak, Ha ditolak (tidak ada nilai). Oleh karena itu, berdasarkan hasil pengujian sebelumnya, t-tabel adalah $41.209>1.984$, yang berarti bahwa $\mathrm{HO}$ ditolak dan Ha diterima, yang berarti bahwa kualitas layanan $(\mathrm{X})$ adalah penting. - Kekuasaan. penting untuk kepuasan pelanggan $(\mathrm{Y})$

\section{E. KESIMPULAN}

Hasil penelitian untuk mengetahui dampak kualitas layanan terhadap kepuasan pelanggan Starbucks Coffee Plaza Kampung Kemang dapat diringkas sebagai berikut:

1. Kualitas layanan di Starbucks Coffee Plaza Kampung Kemang dapat disimpulkan bahwa kualitas layanan di Starbucks Coffee Plaza Kampung Kemang sangat baik, berdasarkan tanggapan responden terhadap kualitas layanan dengan tingkat respons dari pernyataan yang disepakati (S) adalah $68,1 \%$, dan tingkat respons ( SS) adalah $4,4 \%$.

2. Starbucks Coffee Plaza Kampung Kemang berdasarkan peringkat layanan pelanggan Starbucks Coffee Plaza Kampung Kemang sangat baik dalam hal kualitas layanan yang diberikan oleh Starbucks Coffee Plaza Kampung Kemang, menunjukkan respons pelanggan terhadap kepuasan pelanggan dan tingkat respons dengan deklarasi kontrak (S) sebesar $65,7 \%$, dan oleh pernyataan kontrak (SS) sebesar $4,6 \%$.

3. Dampak Kualitas Pelayanan Terhadap Kepuasan Pelanggan di Starbucks Coffee Plaza Kampung Kemang Dari Peringkat Saat Ini, Perhitungan Nilai Produk Terkenal $r=0,886$ berarti kualitas layanan dan kepuasan Hubungan yang Kuat. dari pelanggan atau hubungan antara variabel $X$ dan variabel $Y$, atau dengan kata lain, semua layanan yang disediakan atau dilakukan di Starbucks Coffee Plaza Kampung Kemang memiliki hubungan pelanggan yang memuaskan. Antara kualitas layanan $(X)$ dan kepuasan pelanggan $(\mathrm{Y})$ ada hubungan yang signifikan, yang dibuktikan dengan hasil uji hipotesis yang menghasilkan $t_{\text {_ }}$ (angka) $>\mathrm{t}$ _table, yaitu, 41.209> 1.984. Efisiensi adalah 88,6\% dan sisanya $11,4 \%$ dipengaruhi oleh sejumlah faktor lain yang tidak ditangani oleh penulis.

\section{DAFTAR PUSTAKA}

Freddy, Rangkuti. 2002. Mengukur Kepuasan Pelanggan (Edisi Ketiga). Jakarta: Perpustakaan PT.Gramedia.

Kotler, Philips dan A.B. Susanto. 2000. Layanan manajemen pemasaran di Indonesia, 
Volume 3 • Nomor 2 • Februari 2020

Pege (Hal.) : $40-47$

(C) Universitas Pamulang

JL.Surya Kencana No.1 Pamulang, Tangerang Selatan - Banten Telp. (021) 7412566, Fax (021) 7412491

website. : Email : jurnalmarketing.unpam@gmail.com

http://www.openjournal.unpam.ac.id/index.php/JPK Email : Keempat.

Kotler, Philips. Manajemen Penjualan (Benjamin Molan.). Edisi Milenium Saya adalah Edisi Kesebelas. Jakarta: Prenhallindo.

Margono. 2004. Metode Penelitian Pendidikan. Jakarta: Desain Kreatif.

Nasution, M. Nur. 2004. Manajemen Layanan Terpadu. Jakarta: Ghalia Indonesia.

Rambat, Lupiyoadi. 2004. Manajemen dalam manajemen bisnis: Teori dan metodologi. Jakarta: PT Salemba Four

Sugiyono. 2010. Penelitian tentang metode pendidikan kuantitatif, kulaitatif, dan R\&D di Bandung: CV. Alpha Beta.

Sugiyono. 2007. Metode Penelitian Karir. Bandung: CV. Alpha Beta

Sumarwan, ayolah. 2011. Teori perilaku dan penerapannya pada pemasaran. Jakarta: Ghalia Indonesia.

Lakukan itu, Fandi. 2004. Edisi Keempat. Standar kualitas layanan lengkap (TQS). Yogyakarta: ANDA.

Nella Octaviani. 2013. Publikasi ilmiah. Dampak kualitas layanan terhadap kepuasan pelanggan dengan kopi di Semarang.

Hasibuan, Melayu S.P. 2011. Manajemen Sumber Daya Manusia. Literasi di tanah, Jakarta

Kotler, Philip dan Kevin Lane Keller. 2012. Manajemen Penjualan 13. New Jersey: Pearson Prentice Hall, Inc.

Sunyoto. 2013. Metode dan alat untuk penelitian ekonomi dan bisnis. Caps Publishing: Yogyakarta.

Kotler dan Keller. 2009. Manajemen Pemasaran. Volume 1. Jakarta edisi 13:

Erland.

Tjiptono Fandy. 2014. Layanan Pemasaran, CV Andi Offset: Yogyakarta.

Tjiptono Fandy. 2008. Strategi Pemasaran Edisi Pertama, Perpustakaan Hak Cipta: Bandung. 